\title{
A collective problem of caring
}

\section{Sally Murray}

$\infty$
Without solidarity it is inevitable that we shall ignore distant indignities, violations of human rights, inequities, deprivation of freedom, undemocratic regimes, and damage to the environment. However, if a spirit of mutual caring can be developed between those in wealthy countries and those in developing countries, constructive change is possible. Solomon R. Benatar, Abdallah S. Daar and Peter A. Singer ${ }^{1}$

$\mathrm{W}$ hen we look at the health problems and challenges we face at a global level, we find that all arrows point in the same direction: increasing inequity. Burden of disease is not distributed equally, and nor is access to care and treatment, health risk factors such as injury exposure or tobacco advertising, or the problems we choose to fund, research and think about.

It is easy to find inequity: while polio has been eradicated in developed countries, 200 children in west and central Africa have been permanently paralyzed by the polio virus since mid-2003.

Are ongoing polio infections a fault of poor management of domestic health care systems? Civil war? Poverty? Lack of access to health care? Inadequate funding of health programs? Slow international response, or poorly educated citizens? Or does it really matter where the finger is pointed? Polio may simply offer an example of how multiple factors work together to cause some of our world's citizens to be more vulnerable to disease than others. Are we doing enough to address these problems?

If it is simply an issue of money, probably not. Although a few people have provided sizeable financial assistance - the Bill and Melinda Gates Foundation has put $\$ 5.5$ billion toward global health issues since I994 - country-level support is lacking. Few countries are reaching the target for overseas development assistance of $0.7 \%$ of gross national income promised at the United Nations General Assembly in 1970; most manage less than half. The research dollar is also unlikely to affect health in developing countries in the short term: I3 of I393 new drugs developed between 1975 and 1997 were for tropical diseases. ${ }^{2}$

Is any of this our collective problem? If health problems don't respect boundaries, why should our ethical responsibilities? In 1982 Carol Gilligan wrote about an ethics of caring, explaining that caring develops through a sense of attach涺 ment to and responsibility for others. ${ }^{3}$ With time this develops into a balanced consideration of care for self and others, and notions of universal responsibility. It seems that a sense of attachment to and responsibility for others could go a long way in global health matters.

Even putting altruism aside, taking care of others as a per- sonal responsibility could also be based in self-interest. Increasing globalization of trade, environmental concerns and conflict mean that the problems affecting those in developing countries also affect others: people with tuberculosis travel to countries where the disease is not endemic; disease vector patterns change with global warming; what happens in one country as far as health and its broader determinants go affects others more widely. Looking after the problem in a distant country might stop it coming to yours.

Benatar and colleagues take a similar tack. They talk of developing a "global state of mind" in response to widening disparities in health and subsequent threatened security. ${ }^{1}$ They think that our understanding of civic community needs to be expanded from individual and collective rights and responsibilities to include global (health) responsibilities, and they highlight "long-term self-interest" as a legitimate way of encouraging a global health ethic.

Respect and consideration for others and our environment are based on the understanding that we are all inextricably linked. Caring for others and for the world we live in is part of breathing and living. But to be able to care, we first need to know.

In this issue (see page 33) we launch a new series on global public health issues that is designed to improve "knowing" and to keep global health on the "responsibilities radar" of $C M A J$ readers. It highlights projects and programs that are improving global health and draws attention to particular challenges of some health problems. The series provides a snapshot rather than an overview of the challenges facing disease and risk control in developing countries; it doesn't attempt to - and cannot - be all-inclusive. Our aim is to incite readers to reflect more, to care, and to accept and act on our global responsibility to improve the health of others. And, hopefully, to persuade those readers who already care that there are things that can be done.

Sally Murray is Editorial Fellow at CMAJ.

\section{REFERENCES}

I. Benatar SR, Daar AS, Singer PA. Global health ethics: the rationale for mutual caring. Int Affairs 2003;79(I):107-38.

2. Trouiller P, Olliaro P, Torreele E, et al. Drug development for neglected diseases: a deficient market and a public-health policy failure. Lancet 2002;359:2188-94.

3. Gilligan C. In a different voice: psychological theory and women's development. Cambridge: Harvard University Press; 1982.

Correspondence to: Dr. Sally Murray, CMAJ, 1867 Alta Vista Dr., Ottawa ON KIG 3Y6; fax 6I3 565-547I; sally.murray@cma.ca 